\title{
Directed introduction of DNA cleavage sites to produce a high-resolution genetic and physical map of the Acinetobacter sp. strain ADP1 (BD413UE) chromosome
}

\author{
Elizabeth M. Gralton, $\uparrow$ Alan L. Campbell and Ellen L. Neidle \\ Author for correspondence: Ellen L. Neidle. Tel: +1 706542 2852. Fax: +1 7065422674. \\ e-mail: ENeidle@uga.cc.uga.edu
}

Department of

Microbiology, University of

Georgia, Athens,

GA 30602, USA
The natural transformability of the soil bacterium Acinetobacter sp. ADP1 (BD413UE), formerly classified as A. calcoaceticus, has facilitated previous physiological and biochemical investigations. In the present studies, the natural transformation system was exploited to generate a physical and genetic map of this strain's 3780 191 kbp circular chromosome. Previously isolated Acinetobacter genes were modified in vitro to incorporate a recognition sequence for the restriction endonuclease Notl. Following transformation of the wild-type strain by the modified DNA, homologous recombination placed each engineered Notl cleavage site at the chromosomal location of the corresponding gene. This allowed precise gene localization and orientation of more than $\mathbf{4 0}$ genes relative to a physical map which was constructed with transverse alternating field electrophoresis (TAFE) and Southern hybridization methods. The positions of NotI, Ascl and I-Ceul recognition sites were determined, and the latter enzyme identified the presence of seven ribosomal RNA operons. Multiple chromosomal copies of insertion sequence IS1236 were indicated by hybridization. Several of these copies were concentrated in one region of the chromosome in which a spontaneous deletion of approximately $100 \mathrm{kbp}$ occurred. Moreover, contrary to previous reports, ColE1-based plasmids appeared to replicate autonomously in Acinetobacter sp. ADP1.

Keywords: Acinetobacter, genome, map, PFGE (pulsed-field gel electrophoresis), TAFE (transverse alternating-field electrophoresis)

\section{INTRODUCTION}

Eubacteria of the genus Acinetobacter, classified in the $\gamma$ subdivision of the Proteobacteria (Rainey et al., 1994), are Gram-negative, strictly aerobic and ubiquitous in the environment (Baumann et al., 1968; Juni, 1978). Acinetobacter strains can degrade a wide range of organic compounds including aliphatic alcohols, amino acids, dicarboxylic and fatty acids, alkanes and many aromatic compounds (Juni, 1978). The potential use of bacteria for bioremediation has led to renewed interest in the catabolic abilities of Acinetobacter strains. Re-

†Present address: Department of Chemistry, United States Military Academy, West Point, NY 10996, USA

Abbreviation: TAFE, transverse alternating-field electrophoresis. newed interest in Acinetobacter physiology also stems from the ability of some isolates to cause nosocomial infections, especially those associated with immunocompromised patients (Bergogne-Bérézin, 1994).

Epidemiological investigations have spearheaded new taxonomic studies (Gerner-Smidt, 1994). Acinetobacter classification has historically been confusing due to the nondescript phenotype of this genus and the misidentification of individual strains. Strains now known to be acinetobacters were originally classified into more than 10 different genera (Towner et al., 1991). One method for identification of Acinetobacter strains involves the transformation of a particular trpE auxotroph. DNA from only Acinetobacter strains can transform the auxotroph to prototrophy (Juni, 1972). This $\operatorname{trpE}$ auxotroph is an ideal recipient strain because it is naturally competent for transformation. 
Only strains which can trace their lineage to the encapsulated soil isolate BD4 (Juni \& Janik, 1969) have been found to be naturally competent. ADP1, also designated BD413UE, is an unencapsulated (UE), naturally competent derivative of $\mathrm{BD} 4$ that was an intermediate in the isolation of the $\operatorname{tr} p E$ auxotroph (Juni \& Janik, 1969). ADP1 has been the subject of numerous investigations, including studies of aromatic compound degradation (Ornston \& Neidle, 1991; Harwood \& Parales, 1996). The natural competence of ADP1 has enabled a genetic approach to biochemical and physiological questions that could not have been readily addressed in other ways. This mapping project was undertaken to further the development of genetic techniques. In these studies, exploitation of the natural transformation system of ADP1 was central to the precision with which genes could be localized.

Modified plasmid DNA was used to transform Acinetobacter recipient strains and introduce novel restriction endonuclease recognition sites in the chromosome. The positions of these recognition sites were determined by a combination of Southern hybridization techniques and a type of pulsed-field gel electrophoresis, transverse alternating field electrophoresis (TAFE). Mapping studies will contribute to ongoing investigations of Acinetobacter genetic organization, function and evolution. In previous studies, RP4-mediated conjugation was used to determine the relative locations of 23 different markers on a linkage map of A. calcoaceticus strain EBF65/65 (Towner, 1978). Although circularity of the chromosome was demonstrated, the gene transfer frequency of this method was low, and it was not possible to deduce the distance between the markers (Towner et al., 1991). The methods used here not only demonstrated the circularity and size of the ADP1 chromosome, but allowed gene orientation on a high-resolution correlated physical and genetic map.

\section{METHODS}

Strains, plasmids and growth conditions. The wild-type Acinetobacter sp. strain ADP1 is the unencapsulated BD413 (ATCC 33305) isolated by Juni \& Janik (1969). The taxonomic classification of this strain, formerly A. calcoaceticus, has been called into question (Stratz et al., 1996), prompting the use of Acinetobacter sp. until further characterization is complete. ADP1-derived mutants and plasmids are listed in Table 1. Escherichia coli plasmid-host strains DH5 $\alpha$ (Bethesda Research Laboratories), JM109 (Yanisch-Perron et al., 1985) and Top $10 \mathrm{~F}^{\prime}$ (Invitrogen) were used. The sources of the $\Omega \mathrm{Km}$ and $\Omega \mathrm{SmSp}$ cassettes were pUI1637 and pUI1638, respectively (Eraso \& Kaplan, 1994). Bacteria were grown at $37^{\circ} \mathrm{C}$ with aeration in Luria-Bertani broth (LB) or succinate minimal medium supplemented with antibiotics (Sambrook et al., 1989; Shanley et al., 1986).

DNA manipulations and construction of mutant strains. Standard methods were used for plasmid and chromosomal DNA purification, ligations, E. coli competent cell preparations and E. coli transformations (Sambrook et al., 1989). Purification kits (Qiagen or GeneClean from Bio101) were used to extract DNA fragments from agarose. Restriction enzymes were purchased from Promega, New England Biolabs or Boehringer Mannheim. NotI, I-CeuI and AscI were from New England Biolabs.

Plasmids carrying $\Omega$-disrupted regions of Acinetobacter sp. DNA were linearized with restriction endonucleases and used to alter the ADP1 chromosome as previously described (Neidle et al., 1989). In some cases, a mutation in one Acinetobacter strain was incorporated into the chromosome of a second strain by making a crude DNA lysate of the first strain, by the method of Juni (1972), and using it to transform the second strain. This method was used to transfer the Tn5-disrupted epsX allele from strain BD4:171 (Stark, 1996) to the ADP1 chromosome, generating ACN16.1 (Table 1). Following the selection of mutants by antibiotic resistance, Southern hybridization methods confirmed chromosomal configurations.

Southern hybridization analyses. A rapid downward transfer system (TurboBlotter; Schleicher and Schuell) was used for Southern hybridizations (Sambrook et al., 1989) to transfer DNA to Nytran nylon membranes. To facilitate the transfer of large DNA fragments, acid depurination was used and followed by base cleavage according to the manufacturer's instructions (Schleicher and Schuell). The only variation from suggested protocols was the use of a long transfer time, 18-24 h. Following DNA transfer, DNA was cross-linked to the membranes by exposure to a total dose of UV light $(254 \mathrm{~nm})$ of $120 \mathrm{~mJ} \mathrm{~cm}^{-2}$.

Nonradioactive probes were prepared by labelling DNA fragments with digoxigenin and a random-primed labelling system (Genius System, Boehringer Mannheim). Prehybridization, hybridization (at $42{ }^{\circ} \mathrm{C}$ in $50 \%, v / v$, formamide) and high-stringency washes were done according to the manufacturer's instructions (Boehringer Mannheim). These instructions were also followed for the detection of probes with anti-digoxigenin alkaline phosphatase conjugates and chemiluminescent substrates.

Preparation of intact genomic DNA and restriction digestion for TAFE analysis. Genomic DNA was prepared, from cells grown to stationary phase, in agarose plugs by the method of Smith \& Cantor (1987). Restriction endonuclease digests were performed on the agarose-embedded DNA, using 8-15 units of enzyme with its corresponding commercial restriction buffer. Approximately one-eighth of the gel plug was sliced and equilibrated on ice with buffer and enzyme as described by Suwanto \& Kaplan (1989). Digests were incubated for 6-8 h with gentle shaking (5-10 r.p.m.). Digests with two restriction endonucleases were done sequentially. After the initial digestion, the buffer/enzyme mixture was removed and replaced with $300 \mu \mathrm{l} 1 \times$ TE $(10 \mathrm{mM}$ Tris/ $\mathrm{HCl}, 1 \mathrm{mM}$ EDTA, pH 8.0) and placed on ice for $15 \mathrm{~min}$. This procedure was repeated four times before the second restriction endonuclease buffer was added and allowed to equilibrate on ice. After digestion, the buffer/enzyme mixture was removed and $200 \mu \mathrm{l}$ ESP solution (Smith \& Cantor, 1987) was added, incubated at $55^{\circ} \mathrm{C}$ for $10-15 \mathrm{~min}$ and then removed. The plug was placed in $300 \mu \mathrm{l} 1 \times$ TE for $20-30 \mathrm{~min}$ at $4{ }^{\circ} \mathrm{C}$ prior to being placed in the well of the electrophoresis gel.

TAFE conditions. TAFE (Geneline II, Beckman) gels were formed from either $0.7 \%$ low-melting-point agarose (SeaPlaque from FMC Bioproducts) or 1\% agarose (Seakem GTG from FMC Bioproducts). For low-melting-point gel electrophoresis, the running buffer temperature was $7 \pm 1{ }^{\circ} \mathrm{C}$, while the $1 \%$ agarose gels were maintained at $12 \pm 1{ }^{\circ} \mathrm{C}$. DNA fragments of known sizes were used as standards. Yeast chromosomal standards (Promega), a low-range lambda concatemeric ladder, $\lambda^{\text {LR }}$ (New England BioLabs), and the 
Table 1. Mapped genes, hybridization probes, relevant plasmids and mutant strains

\begin{tabular}{|c|c|c|c|c|}
\hline Locus & $\begin{array}{c}\text { Gene } \\
\text { product(s) }\end{array}$ & $\begin{array}{c}\text { Relevant } \\
\text { plasmid(s) }\end{array}$ & $\begin{array}{l}\text { ADPl-derived } \\
\text { mutant }(s)\end{array}$ & $\begin{array}{l}\text { Reference }(s) \text { or } \\
\text { source }\end{array}$ \\
\hline $\begin{array}{l}\text { alkR, alkM, } \\
\text { orf } \mathrm{Y}\end{array}$ & Alkane degradation & $\begin{array}{l}\mathrm{pWH} 785 \\
\mathrm{pBAC} 72, \Omega \mathrm{Km} \text { in orf } \\
\text { near alkR }\end{array}$ & 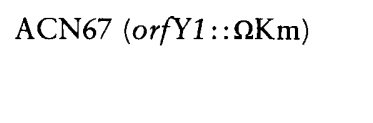 & A. Ratajczak \& W. Hillen ${ }^{1}$ \\
\hline benM & $\begin{array}{l}\text { Regulator of benzoate } \\
\text { degradation }\end{array}$ & $\begin{array}{l}\text { pBAC11 } \\
\text { pBAC } 58, \Omega S p S m \text { in } \\
\text { benM SalI site }\end{array}$ & $\begin{array}{l}\text { ACN53 (benM2::SSpSm) } \\
\text { ACN55 (benM } 2:: \Omega \text { SpSm, } \\
\text { recA ::Tn5) }\end{array}$ & L. Collier \& E. Neidle \\
\hline catA & Catechol oxygenase & pIB1343 & & Neidle et al. (1987) \\
\hline catM & $\begin{array}{l}\text { Regulator of catechol } \\
\text { degradation }\end{array}$ & $\begin{array}{l}\text { pIB15 } \\
\text { pBAC6A, } \Omega \mathrm{Km} \text { in catM } \\
\text { HincII site }\end{array}$ & ACN6.1 (catM1:: $\Omega \mathrm{Km})$ & Neidle et al. (1989) \\
\hline epsX, epsM & $\begin{array}{l}\text { Exopolysaccharide } \\
\text { formation }\end{array}$ & pNP2345 & $\begin{array}{l}\text { ACN16.1 (epsX:: } \operatorname{Tn} 5) \\
\text { ACN29 (epsX::Tn5, trp- } \\
1:: \Omega S p S m)\end{array}$ & Stark (1996) \\
\hline est $A, \operatorname{rot} A$ & Esterase, isomerase & $\begin{array}{l}\text { pAKA24-5 } \\
\text { pBAC } 69, \Omega \mathrm{Km} \text { in est } \\
\text { Clal site }\end{array}$ & 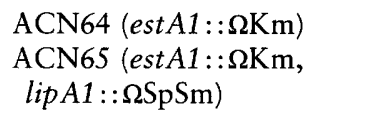 & Kok (1995), Kok et al. (1993) \\
\hline est $B$, est $R$ & Lipase, regulator & $\begin{array}{l}\text { pAKA22- } 20 \\
\text { pBAC } 59, \Omega S p S m \text { in est } \\
\text { PmlI site }\end{array}$ & $\mathrm{ACN} 45$ (estR1:: $\Omega \mathrm{SpSm})$ & Kok (1995), Kok et al. (1993) \\
\hline IS1236 & Insertion sequence & pZR2016 & & $\begin{array}{l}\text { Gerischer \& Ornston (1995), } \\
\text { Gerischer et al. (1996) }\end{array}$ \\
\hline $\operatorname{lip} A, \operatorname{lip} B$ & Lipases & $\begin{array}{l}\text { pALJA434 } \\
\text { pBAC } 56, \Omega S p S m \text { in lipA } \\
\text { EcoRI site }\end{array}$ & 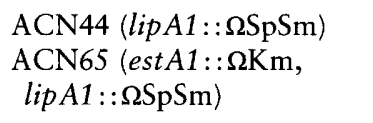 & Kok $(1995)$ \\
\hline$m u c K$ & $\begin{array}{l}\text { cis,cis-Muconate } \\
\text { transporter }\end{array}$ & $\begin{array}{l}\text { pADPW1 } \\
\text { pBAC101, } \Omega S p S m \text { in } \\
m u c K \Delta N s i \text { site }\end{array}$ & $\mathrm{ACN79}(m u c K 1:: \Omega S \mathrm{pSm})$ & P. A. Williams ${ }^{2}$ \\
\hline$p c a$ genes & $\begin{array}{l}\text { Protocatechuate } \\
\text { degradation }\end{array}$ & pZR6 & ADP212 (pcaD104:: Tn5) & $\begin{array}{l}\text { Doten et al. (1987), Gregg- } \\
\text { Jolly \& Ornston (1990) }\end{array}$ \\
\hline pobA & $\begin{array}{l}\text { 4-Hydroxybenzoate } \\
\text { hydroxylase }\end{array}$ & pZR405 & & Averhoff et al. (1992) \\
\hline$q u i A B C$ & Quinate degradation & pZR504 & & Elsemore \& Ornston (1994) \\
\hline$r e c A$ & RecA protein & pZR106 & $\begin{array}{l}\text { ADP197 (recA:: } \operatorname{Tn} 5) \\
\text { ACN55 (benM2::SSpSm, } \\
\text { recA ::Tn5) }\end{array}$ & $\begin{array}{l}\text { Gregg-Jolly \& Ornston } \\
(1994)\end{array}$ \\
\hline$r p o N$ & $\begin{array}{l}\text { RNA polymerase } \sigma^{54} \\
\text { subunit }\end{array}$ & $\begin{array}{l}\mathrm{pWH} 837 \\
\mathrm{pBAC} 71, \Omega \mathrm{Km} \text { in } r p o N \\
\text { SnaBI site }\end{array}$ & 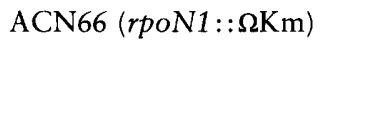 & $\begin{array}{l}\text { F. Schirmer, B. Argauer \& } \\
\text { W. Hillen }{ }^{1}\end{array}$ \\
\hline$r u b A B$ & Alkane degradation & pWH891 & & Geissdörfer et al. (1995) \\
\hline $\operatorname{Tn} 5$ & Transposon & & $\begin{array}{l}\text { ISA } 1000.3 \text {, ISA } 1000.5(\operatorname{Tn} 5 \\
\text { in NotI fragment C, Tn5 } \\
\text { in NotI fragment A) }\end{array}$ & G. L. Gaines ${ }^{3}$ \\
\hline $\operatorname{trpFB}$ & Tryptophan biosynthesis & $\begin{array}{l}\text { pJK15 } \\
\text { pBAC } 46, \Omega S p S m \text { in } \\
\text { BspEI site upstream of } \\
\operatorname{trpF}\end{array}$ & $\begin{array}{l}\text { ACN27 (trp-1::SSpSm) } \\
\text { ACN29 (epsX::Tn5, trp- } \\
1:: \Omega S p S m)\end{array}$ & Ross et al. (1990) \\
\hline $\operatorname{trp} G D C$ & Tryptophan biosynthesis & $\begin{array}{l}\mathrm{pBN} 78 \\
\mathrm{pBAC} 51, \Omega S \mathrm{pSm} \text { in } \operatorname{trpD} \\
\text { PstI site }\end{array}$ & 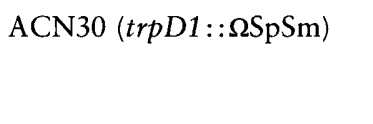 & Kaplan et al. (1984) \\
\hline $\operatorname{trp} E$ & Tryptophan biosynthesis & $\begin{array}{l}\mathrm{pWH} 1705 \\
\mathrm{pBAC} 95, \Omega \mathrm{Km} \text { in } \operatorname{trp} E \\
\Delta \text { ClaI site }\end{array}$ & $\mathrm{ACN} 74(\operatorname{trp} 11:: \Omega \mathrm{Km})$ & Haspel et al. (1990) \\
\hline
\end{tabular}

*pBAC plasmids and ACN strains were constructed for these studies. Affiliations of sources: 1, Friedrich-Alexander-Universität, Erlangen-Nürnberg, Germany; 2, University of Wales, Bangor, UK; 3, Isogenetics, Inc., Chicago, IL, USA. 
lambda 39 concatemeric ladder, $\lambda^{39}$ (Promega) provided a wide range of fragment sizes.

Three protocols were used with different pulse and run times to separate DNA fragments of various sizes. An $18 \mathrm{~h}$ protocol with two stages maximized resolution of $500-1500 \mathrm{kbp}$ fragments. The first stage used $350 \mathrm{~mA}$ of constant current with a pulse time of $45 \mathrm{~s}$ for $12 \mathrm{~h}$. The second used $370 \mathrm{~mA}$ of current with a pulse time of $90 \mathrm{~s}$ for $6 \mathrm{~h}$. A $26 \mathrm{~h}$ protocol, maximizing resolution of $50-500 \mathrm{kbp}$ fragments, used four stages: (1) $350 \mathrm{~mA}, 30 \mathrm{~s}$ pulses, $5 \mathrm{~h}$; (2) $370 \mathrm{~mA}, 45 \mathrm{~s}$ pulses, $8 \mathrm{~h}$; (3) $370 \mathrm{~mA}, 60 \mathrm{~s}$ pulses, $8 \mathrm{~h}$; (4) $390 \mathrm{~mA}, 90 \mathrm{~s}$ pulses, $5 \mathrm{~h}$. A $30 \mathrm{~h}$ protocol maximized separation of fragments in the 10-300 kbp range and used four stages: (1) $350 \mathrm{~mA}$, $20 \mathrm{~s}$ pulses, $6 \mathrm{~h}$; (2) $350 \mathrm{~mA}, 30 \mathrm{~s}$ pulses, $12 \mathrm{~h}$; (3) $370 \mathrm{~mA}$, $45 \mathrm{~s}$ pulses, $10 \mathrm{~h}$; (4) $370 \mathrm{~mA}, 60 \mathrm{~s}$ pulses, $2 \mathrm{~h}$.

\section{RESULTS}

\section{Selection of restriction enzymes and genome size}

The restriction endonucleases NotI and $A s c \mathrm{I}$, with $\mathrm{G}+\mathrm{C}$-rich recognition sequences, cleaved the $\mathrm{A}+\mathrm{T}$ rich chromosome of ADP1 into six and sixteen DNA fragments, respectively. I-CeuI, with a 26-nucleotide recognition sequence (Liu et al., 1993), cleaved the genome into seven fragments. DNA fragments between 5 and $1500 \mathrm{kbp}$ were separated using the GeneLine II TAFE system (Beckman) with three different protocols (see Methods). Analysis of undigested wild-type genomic DNA was consistent with a single chromosome with no endogenous plasmids (data not shown). Genomic fragments generated by digestion with NotI and I-CeuI were designated $\mathrm{A}$ to $\mathrm{F}$ and I to VII, respectively (Fig. 1, Table 2). Although similar use of AscI resulted in 11 distinct bands (Fig. 1c), the relative intensities indicated that some represented more than one DNA fragment. Bands 6 (192 kbp), 9 (77 kbp) and 11 (23 kbp) may each correspond to two distinct DNA fragments, and band $8(113 \mathrm{kbp})$ may represent three fragments. The genome size was deduced from the sizes of individual fragments following restriction endonuclease cleavage (Table 2). Fragment sizes were based on the means of 102 digests of the wild-type strain with NotI, 32 with I-CeuI and 27 with AscI. Analyses of mutant strains, described below, were also included in the estimation of a $3780 \pm 191 \mathrm{kbp}$ chromosome.

\section{Construction of the physical map; location of Notl- generated fragments}

Incomplete cleavage of genomic DNA with NotI generated four DNA fragments in addition to fragments $A$ to $F$. Three were intermediate in size between fragments $C$ and $D$, indicating that fragments $D, E$ and $F$ were adjacent on the chromosome. The sizes were consistent with the chromosomal order F-D-E. The fourth fragment identified by partial digestion was larger than $\mathrm{C}$ and smaller than B. Its size was equal to the sum of $E$ and $C$, suggesting the chromosomal fragment order F-D-E-C.

Fragments $A$ and $B$ were located relative to F-D-E-C by using small DNA regions at the ends of the six NotI fragments as hybridization probes. These small fragments were isolated by ligating chromosomal DNA and cloning vector pSL301 (Invitrogen) which had both been cleaved with NotI and the more frequently cutting HindIII. Individual recombinant plasmids were isolated, and the ADP1 DNA inserts, designated junction fragments (JF), were purified. Using Southern hybridization methods, two of these fragments, JF312 and JF306, hybridized to fragment A. JF312 hybridized to I-CeuI fragment II (Fig. 2b), as did probes made from the entire fragments $C$ or A. Use of the JF312 probe with genomic DNA digested by NotI and I-CeuI established the relative positions of fragments $\mathrm{C}, \mathrm{A}$ and II (Fig. 2b).

JF306 hybridized to I-CeuI fragment I (Fig. 2a) and to AscI fragment 3 (summarized in Table 3 and Fig. 3). Since AscI fragment 3 hybridized to both fragments A and B, and since JF306 hybridized to a $68 \mathrm{kbp}$ chromosomal fragment generated by cleavage with NotI and ICeuI, the relative fragment positions were established (Figs $2 \mathrm{a}$ and 3 ). The Not I fragment order was therefore F-D-E-C-A-B. Additional hybridization results established that $B$ and $F$ are adjacent on the chromosome. For example, DNA at the end of NotI fragment B, JF311, hybridized to $A s c \mathrm{I}$ fragment 2, and labelled $A s c \mathrm{I}$ fragment 2 hybridized to both fragments B and F (Table 3, Fig. 3). The order of fragments is depicted on the physical map (Fig. 4).

\section{Location of I-Ceul and Ascl-generated fragments on the physical map}

The assigned locations of I-CeuI I and II (Fig. 4) were consistent with the TAFE patterns after sequential NotI and I-CeuI cleavage (Fig. 2). The positions of I-CeuI fragments III, IV, V, VI and VII, all internal to NotI fragment $A$, were determined with gene probes and mutant strains (Table 1). A probe made to the $615 \mathrm{kbp}$ DNA region between the eps $X$ gene and the end of fragment A (map positions 827-1442) hybridized to ICeuI fragments II, IV and V. Probes made from the $t r p F$ and $\operatorname{trpE}$ markers hybridized to IV, and an epsX probe hybridized to $\mathrm{V}$. The JF312 probe hybridized to the $38 \mathrm{kbp}$ DNA region between map positions 1404 (trpF) and 1442 , thus establishing the positions of fragments IV and $\mathrm{V}$ (Fig. 4). A probe from a region of fragment $\mathrm{A}$ in mutant ISA 1000.5 , map positions $0-421$, hybridized to both fragments VI and III. A lipBA gene probe hybridized to fragment III. A probe made from the largest AscI fragment (1) hybridized strongly to I-CeuI fragments VI, III, VII and V, and weakly to IV. The positions of all the I-CeuI fragments and some of the AscI fragments were thereby determined (Table 3, Fig. 4).

\section{The genetic map: generating mutants with new chromosomal Notl sites}

Interposon mutagenesis introduced NotI recognition sequences at known locations in Acinetobacter sp. DNA. An $\Omega$ cartridge conferring resistance to streptomycin and spectinomycin $(\mathrm{SpSm})$ or kanamycin $(\mathrm{Km})$ was 


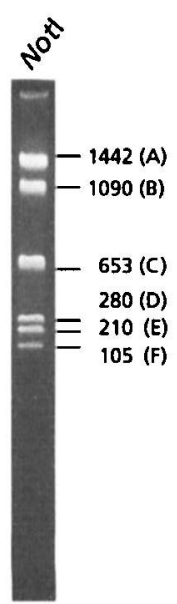

(a)

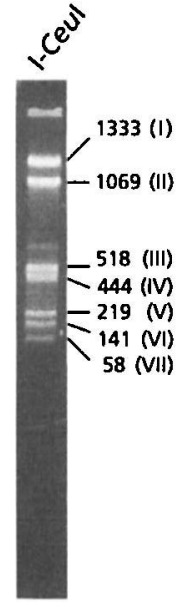

(b)

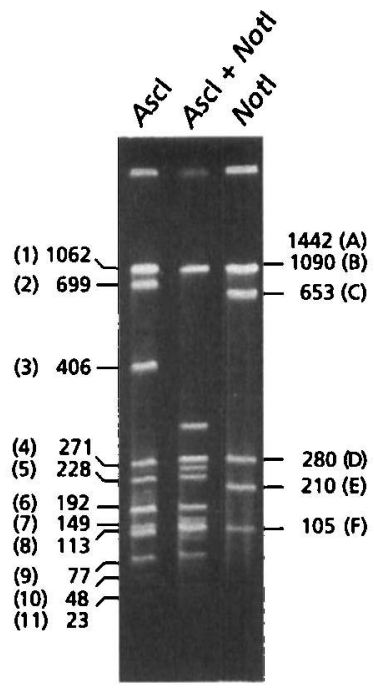

(c)
Fig. 1. Restriction enzyme digests of the ADP1 genome with Notl (a), I-Ceul (b) or Ascl (c). DNA fragment size (in kbp) and fragment designations are indicated adjacent to TAFE gels. Different resolution of Notl fragments resulted from use of the $18 \mathrm{~h}$ (a) and $30 \mathrm{~h}$ (c) TAFE separation protocols.

Table 2. Acinetobacter sp. ADP1 DNA fragment sizes

\begin{tabular}{|c|c|c|c|c|c|}
\hline \multicolumn{2}{|c|}{ Digestion withNotI } & \multicolumn{2}{|c|}{ Digestion with I-CeuI } & \multicolumn{2}{|c|}{ Digestion with $A s c \mathrm{I}$} \\
\hline $\begin{array}{l}\text { Fragment } \\
\text { designation }\end{array}$ & Size $(k b p)$ & $\begin{array}{c}\text { Fragment } \\
\text { designation }\end{array}$ & Size $(\mathbf{k b p})$ & $\begin{array}{c}\text { Fragment } \\
\text { designation }\end{array}$ & Size $(\mathbf{k b p})$ \\
\hline A & $1442 \pm 55$ & I & $1333 \pm 54$ & 1 & $1062 \pm 46$ \\
\hline B & $1090 \pm 27$ & II & $1069 \pm 44$ & 2 & $699 \pm 20$ \\
\hline $\mathrm{C}$ & $653 \pm 22$ & III & $518 \pm 26$ & 3 & $406 \pm 22$ \\
\hline $\mathrm{D}$ & $280 \pm 23$ & IV & $444 \pm 29$ & 4 & $271 \pm 11$ \\
\hline $\mathrm{E}$ & $210 \pm 24$ & $\mathrm{~V}$ & $219 \pm 32$ & 5 & $228 \pm 13$ \\
\hline \multirow[t]{6}{*}{$\mathrm{F}$} & $105 \pm 11$ & VI & $141 \pm 24$ & 6 doublet & $192 \pm 21$ \\
\hline & & VII & $58 \pm 12$ & 7 & $149 \pm 17$ \\
\hline & & & & 8 triplet & $113 \pm 9$ \\
\hline & & & & 9 doublet & $77 \pm 14$ \\
\hline & & & & 10 & $48 \pm 8$ \\
\hline & & & & 11 doublet & $23 \pm 7$ \\
\hline Total: & $3780 \pm 162$ & & $3782 \pm 221$ & & $3786 \pm 189$ \\
\hline
\end{tabular}

inserted into Acinetobacter DNA carried on a recombinant plasmid. Each cartridge, derived from plasmid pUI1637 or pUI1638 (Eraso \& Kaplan, 1994), carried a NotI restriction site adjacent to the drug-resistance determinant. The $\Omega S p S m$ cartridge was inserted in lipA, generating plasmid pBAC56 (Fig. 5a). Plasmids pBAC46, pBAC59, pBAC58, pBAC101 and pBAC51 were constructed by insertion of the $\Omega S \mathrm{pSm}$ cartridge upstream of $\operatorname{trpF}$, within estR, within benM, within mucK and within $\operatorname{tr} p D$, respectively (Table 1 ). The $\Omega \mathrm{Km}$ cartridge was inserted into est $A, \operatorname{trp} E$, rpoN, catM and upstream of alkR, forming pBAC69, pBAC95, pBAC71, pBAC6A and $\mathrm{pBAC72}$ (Table 1).

These $\mathrm{pBAC}$ plasmids were individually linearized with a restriction endonuclease and used to transform strain ADP1. Mutants with a chromosomal copy of an $\Omega$ cartridge were selected by drug resistance. Each drug- resistant mutant had more than six genomic NotI DNA fragments (Fig. 6). The modified DNA appeared to have integrated in the homologous wild-type chromosomal region. For example, a labelled lipA probe (Fig. 5) hybridized to the wild-type NotI fragment A. In the lipA mutant ACN44, fragment $A$ was cleaved into two smaller fragments, A1 (1100 kbp) and A2 (320 kbp) (Figs 5 and 6). The lipA probe hybridized to A2, consistent with the engineered NotI site being in the $5^{\prime}$ region of $\operatorname{lip} A$. The smallest fragment generated by digestion of ACN44 genomic DNA with NotI (Fig. 6) correponded to plasmid DNA, as discussed later.

Probes from catM, benM or alkR hybridized to NotI fragment $\mathrm{E}$. In the corresponding mutants ACN6.1, ACN53 or ACN67, fragment E (210 kbp) was cleaved by NotI into two smaller fragments, E1 and E2 (Fig. 6). E1 and E2 were 170 and $40 \mathrm{kbp}$ in ACN6.1, 160 and $50 \mathrm{kbp}$ 

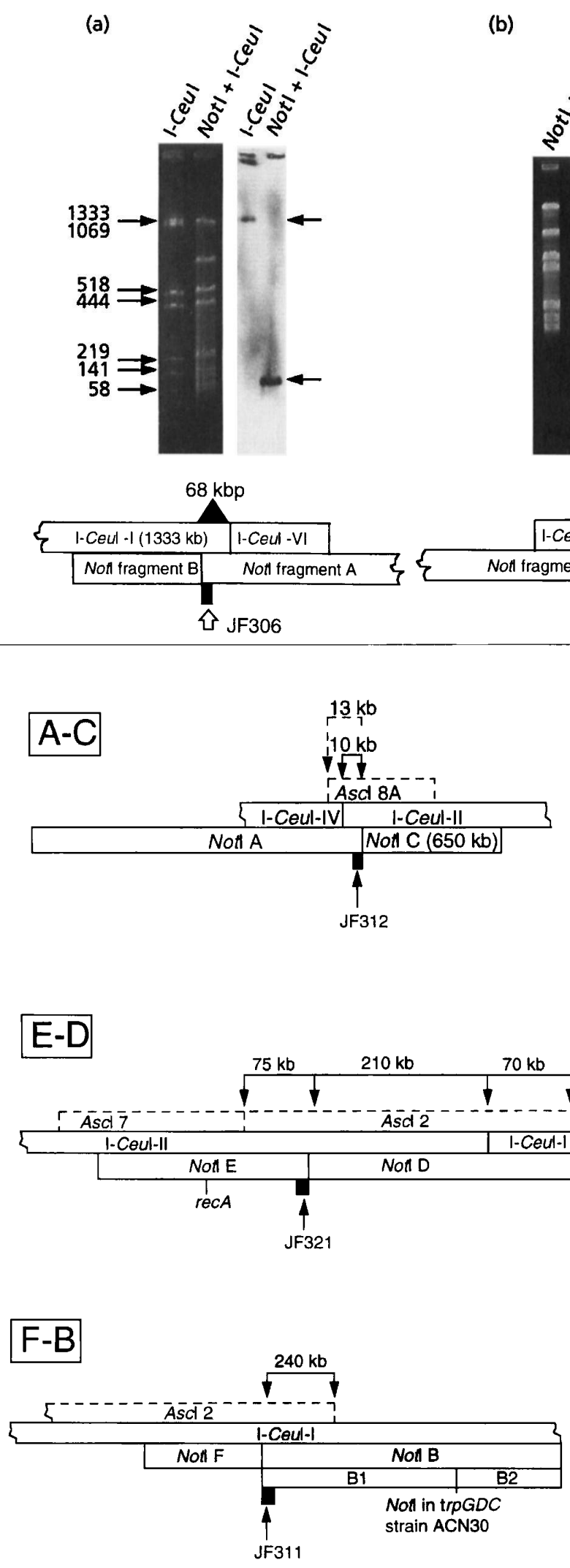

E-D (b)
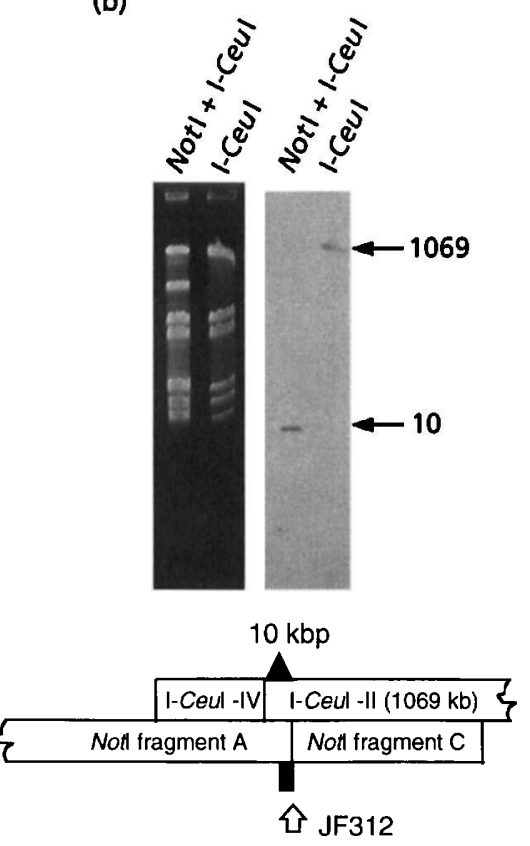

Fig. 2. Southern hybridization analysis of the relative positions of Notl fragments B, A and C. (a). Wild-type DNA digested with the enzymes indicated (TAFE gel, left) was hybridized to a JF306 probe. Solid arrows show the sizes (in kbp) of DNA fragments corresponding to the resultant hybridization signals (right). (b). As in (a) except the JF312 probe was used, DNA from the opposite end of fragment A. Additional experiments distinguished I-Ceul fragments I and II (not shown).
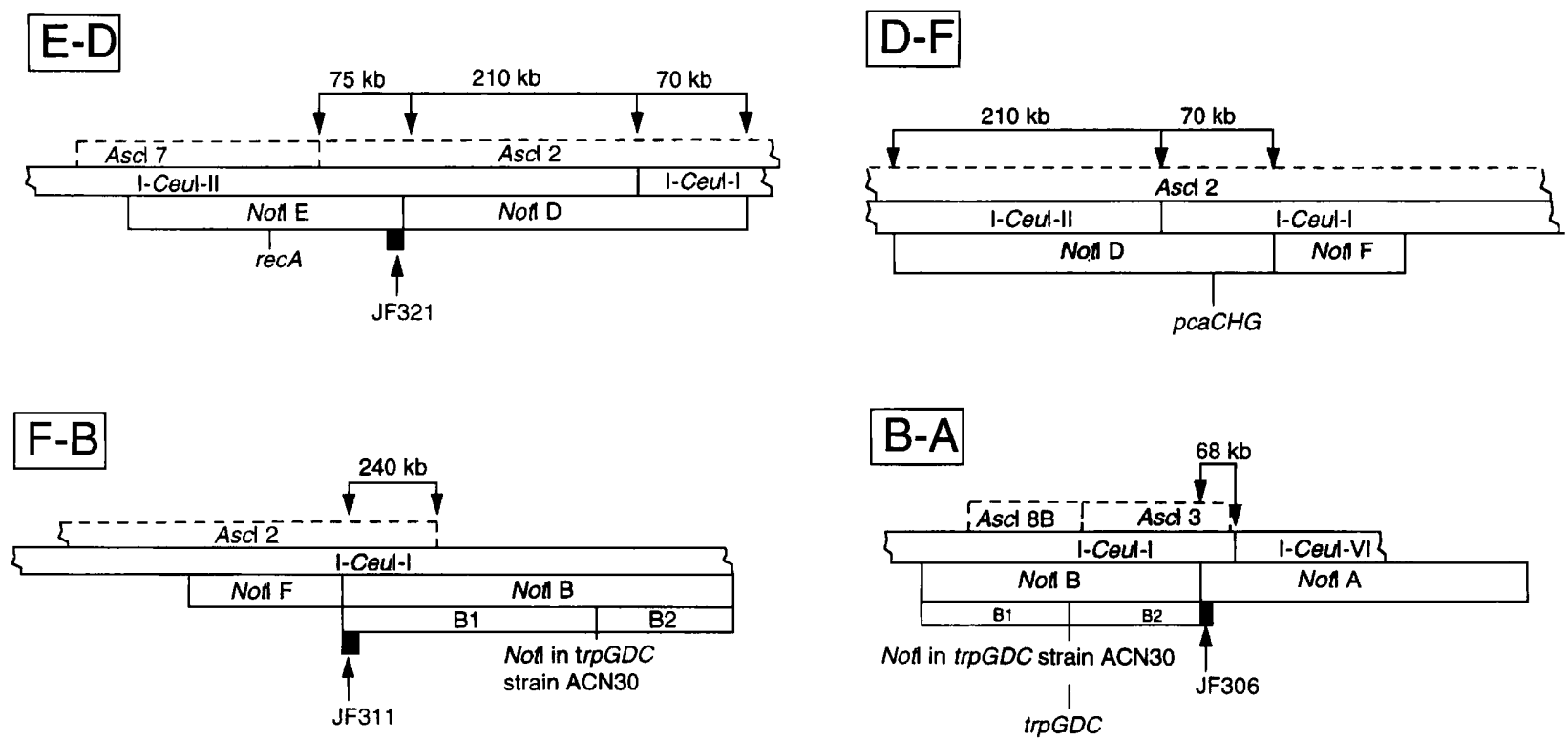

Fig. 3. Representations of Notl fragment junctions. Letters enclosed in boxes indicate the two Notl fragments depicted in each diagram. The relative positions of restriction fragments were deduced from hybridization data (Table 3). 
Table 3. Summary of hybridization studies of the Notl fragment junctions

\begin{tabular}{|c|c|c|c|}
\hline $\begin{array}{l}\text { NotI } \\
\text { junction }\end{array}$ & Labelled probe & $\begin{array}{l}\text { Target DNA* } \\
\text { cleaved by }\end{array}$ & Hybridization detected to \\
\hline \multirow[t]{2}{*}{$\mathrm{A}-\mathrm{C}$} & JF312 & $\begin{array}{l}\text { NotI } \\
\text { I-CeuI } \\
\text { NotI and I-CeuI } \\
\text { AscI } \\
\text { NotI and AscI }\end{array}$ & $\begin{array}{l}\text { NotI fragment A } \\
\text { I-CeuI fragment II } \\
10 \mathrm{kbp} \text { fragment } \\
\text { AscI fragment } 8(113 \mathrm{kbp}) \\
13 \mathrm{kbp} \text { fragment }\end{array}$ \\
\hline & NotI fragment C & $\begin{array}{l}\mathrm{I}-\mathrm{CeuI} \\
\text { NotI and I-CeuI }\end{array}$ & $\begin{array}{l}\text { I-CeuI fragment II } \\
\text { NotI fragment C }\end{array}$ \\
\hline \multirow[t]{2}{*}{$\mathrm{C}-\mathrm{E}$} & JF321 & $\begin{array}{l}\text { NotI (ACN16.1) } \\
\text { AscI }\end{array}$ & $\begin{array}{l}\text { NotI fragment E2 } \\
\text { AscI fragment } 2\end{array}$ \\
\hline & $\begin{array}{l}\text { Fragment C2 of } \\
\text { ISA } 1000.3\end{array}$ & $\begin{array}{l}\text { AscI } \\
\text { NotI and AscI }\end{array}$ & $\begin{array}{l}\text { AscI fragments } 5,8 \\
\text { AscI fragment } 5,100 \mathrm{kbp} \text { fragment }\end{array}$ \\
\hline \multirow[t]{5}{*}{ E-D } & $\operatorname{rec} A$ & $\begin{array}{l}\text { Not } \mathrm{I} \\
\mathrm{I}-C e u \mathrm{I} \\
\text { AscI }\end{array}$ & $\begin{array}{l}\text { Not I fragment } \mathrm{E} \\
\mathrm{I}-\mathrm{Ceu \textrm {I }} \text { fragment II } \\
\text { AscI fragment } 7\end{array}$ \\
\hline & JF321 & $\begin{array}{l}\text { AscI } \\
\text { NotI and AscI }\end{array}$ & $\begin{array}{l}\text { AscI fragment } 2 \\
77 \mathrm{kbp} \text { fragment }\end{array}$ \\
\hline & NotI fragment D & $\begin{array}{l}\mathrm{I}-\mathrm{CeuI} \\
\text { NotI and I-CeuI }\end{array}$ & $\begin{array}{l}\text { I-CeuI fragments I and II } \\
210 \text { and } 70 \mathrm{kbp} \text { fragments }\end{array}$ \\
\hline & NotI fragment $\mathrm{E}$ & AscI & AscI fragments 2 and 7 \\
\hline & I-CeuI fragment II & $\begin{array}{l}\text { NotI } \\
\text { NotI and I-CeuI }\end{array}$ & $\begin{array}{l}\text { NotI fragments C, D and E } \\
\text { NotI fragments C, E and } 210 \mathrm{kbp} \\
\text { portion of D }\end{array}$ \\
\hline \multirow[t]{4}{*}{ D-F } & pcaCHG & $\begin{array}{l}\text { NotI } \\
\text { I-CeuI } \\
\text { NotI and I-CeuI } \\
\text { AscI }\end{array}$ & $\begin{array}{l}\text { NotI fragment D } \\
\text { I-CeuI fragment I } \\
70 \mathrm{kbp} \text { fragment } \\
\text { AscI fragment } 2\end{array}$ \\
\hline & NotI fragment D & $\begin{array}{l}\text { I-CeuI } \\
\text { NotI and I-CeuI }\end{array}$ & $\begin{array}{l}\text { I-CeuI fragments I and II } \\
210 \text { and } 70 \mathrm{kbp} \text { fragments }\end{array}$ \\
\hline & AscI fragment 2 & NotI & Not I fragments B, D, E and F \\
\hline & I-CeuI fragment II & $\begin{array}{l}\text { NotI } \\
\text { NotI and I-CeuI }\end{array}$ & $\begin{array}{l}\text { NotI fragments C, D and E } \\
650 \text { and (2) } 210 \mathrm{kbp} \text { fragments }\end{array}$ \\
\hline \multirow[t]{2}{*}{ F-B } & AscI fragment 2 & $\begin{array}{l}\text { NotI } \\
\text { Not I (ACN30) }\end{array}$ & $\begin{array}{l}\text { Not I fragments B, D, E and F } \\
\text { Not I fragments B1, D, E and F }\end{array}$ \\
\hline & JF311 & $\begin{array}{l}\text { NotI } \\
\text { AscI } \\
\text { NotI and AscI }\end{array}$ & $\begin{array}{l}\text { NotI fragment B } \\
\text { AscI fragment } 2 \\
240 \mathrm{kbp} \text { fragment }\end{array}$ \\
\hline \multirow[t]{5}{*}{ B-A } & JF306 & $\begin{array}{l}\text { NotI and I-CeuI } \\
\mathrm{I}-\mathrm{CeuI} \\
\text { AscI }\end{array}$ & $\begin{array}{l}68 \mathrm{kbp} \text { fragment } \\
\mathrm{I}-\mathrm{CeuI} \text { fragment I } \\
\text { AscI fragment } 3\end{array}$ \\
\hline & NotI fragment A & $\mathrm{I}-\mathrm{CeuI}$ & All seven I-CeuI fragments \\
\hline & AscI fragment 3 & $\begin{array}{l}\text { Not I } \\
\mathrm{I}-\mathrm{CeuI}\end{array}$ & $\begin{array}{l}\text { NotI fragments A and B } \\
\text { I-CeuI fragment I }\end{array}$ \\
\hline & $\begin{array}{l}\text { Fragment B2 of } \\
\text { ACN } 30\end{array}$ & AscI digest & AscI fragments 3 and 8 \\
\hline & $\operatorname{trp} G D C$ & AscI digest & AscI fragment 8 \\
\hline
\end{tabular}

* Wild-type target DNA except where parentheses indicate mutant strains. 


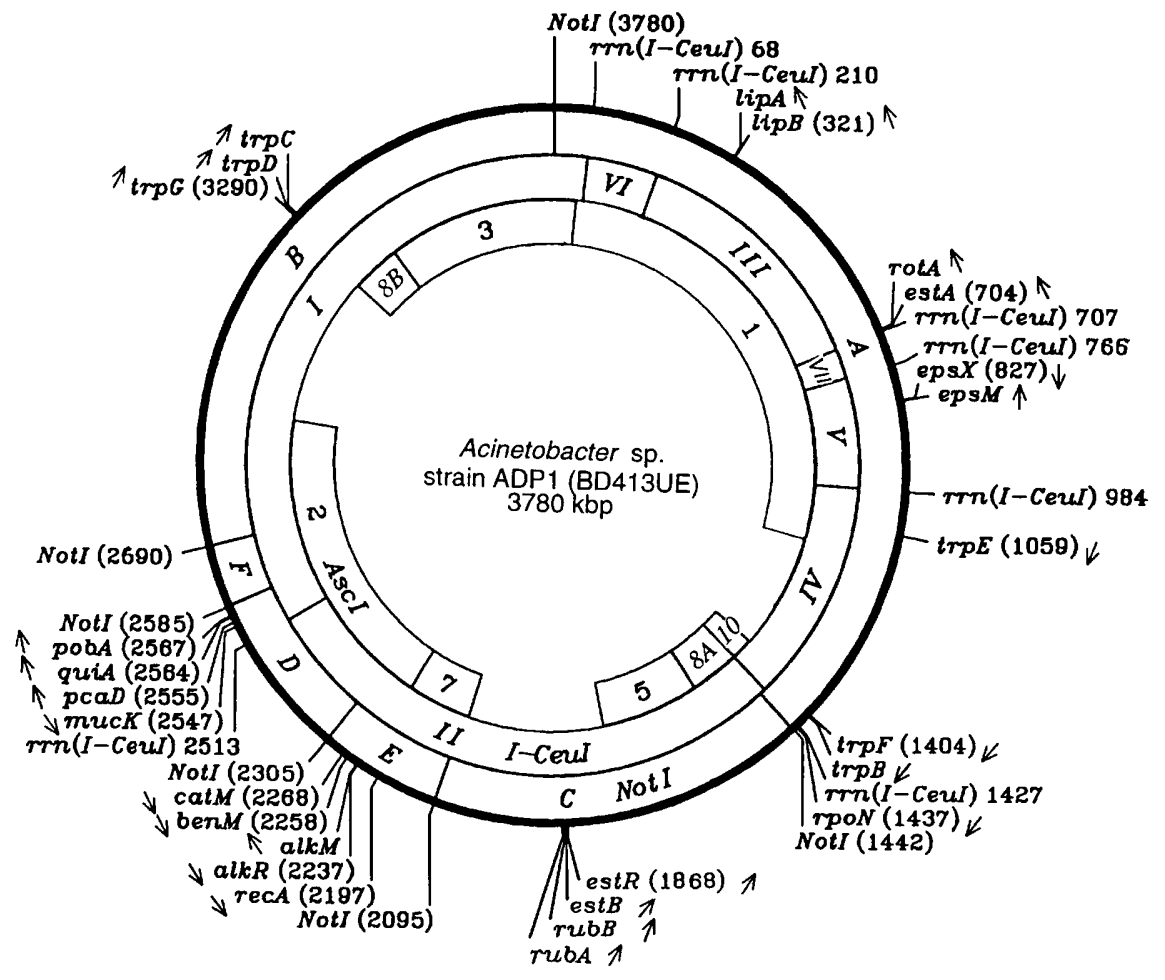

Fig. 4. Physical and genetic map of the chromosome of Acinetobacter sp. strain ADP1 (BD413UE). The origin of the map (0/3780) was arbitrarily located at the Notl fragments B and A junction; position numbers indicate the distance (in kbp) from this origin. Arrows indicate the $5^{\prime}$ to $3^{\prime}$ orientations of genes.

(a)

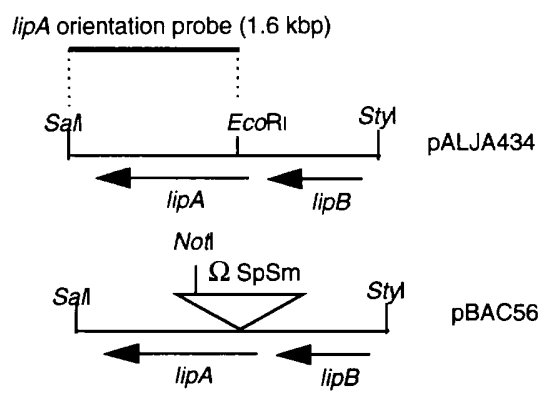

(b)

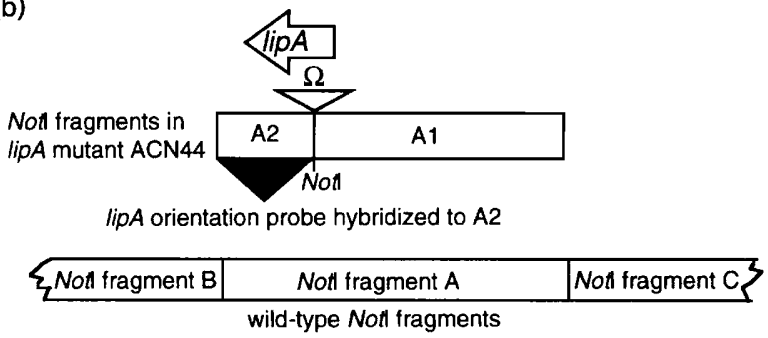

Fig. 5. Representations of lipA on recombinant plasmids (a) or chromosomal fragments (b). Insertion of the $\Omega S p S m$ cartridge (triangle) into the lipA EcoRI site yielded plasmid pBAC56 (a) and mutant ACN44 (b), each with a Notl site in the $5^{\prime}$ end of lipA. A probe to the $3^{\prime}$ end of $\operatorname{lip} A$ (a) indicated the chromosomal orientation of the gene (open arrow in b). Not drawn to scale. in ACN53, and 140 and $70 \mathrm{kbp}$ in ACN67. The smallest NotI DNA fragments of ACN53 and ACN67 (Fig. 6) corresponded to plasmid DNA, as discussed in subsequent sections. Moreover, in ACN67, the observed size of fragment $C\left(C^{*}\right)$ was anomalously low. This size variation appeared to result from a spontaneous deletion in the wild-type strain rather than from insertion of a novel NotI recognition site. Although the wild-type NotI fragment C was determined to be $653 \mathrm{kbp}$, a change was noted in its size during these studies, resulting in the observed size of $550 \mathrm{kbp}$ in some strains $\left(\mathrm{C}^{*}\right.$, Fig. 6). A spontaneous deletion in a laboratory isolate of ADP1 (lane 1, Fig. 6) could have been maintained in mutants which were constructed using the deleted wild-type strain as the recipient for transformation by modified DNA.

Labelled DNA from $\operatorname{trpF}$, est $A$, $r p o N$ or $\operatorname{tr} p E$ hybridized to the wild-type fragment $A$. DNA from the corresponding mutants ACN27, ACN64, ACN66 and ACN74 yielded fragments $\mathrm{A} 1$ and $\mathrm{A} 2$ after Not I cleavage (Fig. 6 ). In the rpoN mutant ACN66 and in ACN27 ( $\Omega$ near $\operatorname{trpF)}$ the A1 fragments were close in size to A and the A2 fragments were 5 and $40 \mathrm{kbp}$, respectively. In the est $A$ mutant ACN64, A1 and A2 were 740 and $700 \mathrm{kbp}$, and in the trpE mutant ACN74 they were 1060 and $380 \mathrm{kbp}$. Two of these strains, ACN66 and ACN74, were found to have the smaller fragment $\mathrm{C}^{*}$ rather than the expected $653 \mathrm{kbp}$ fragment $\mathrm{C}$. 


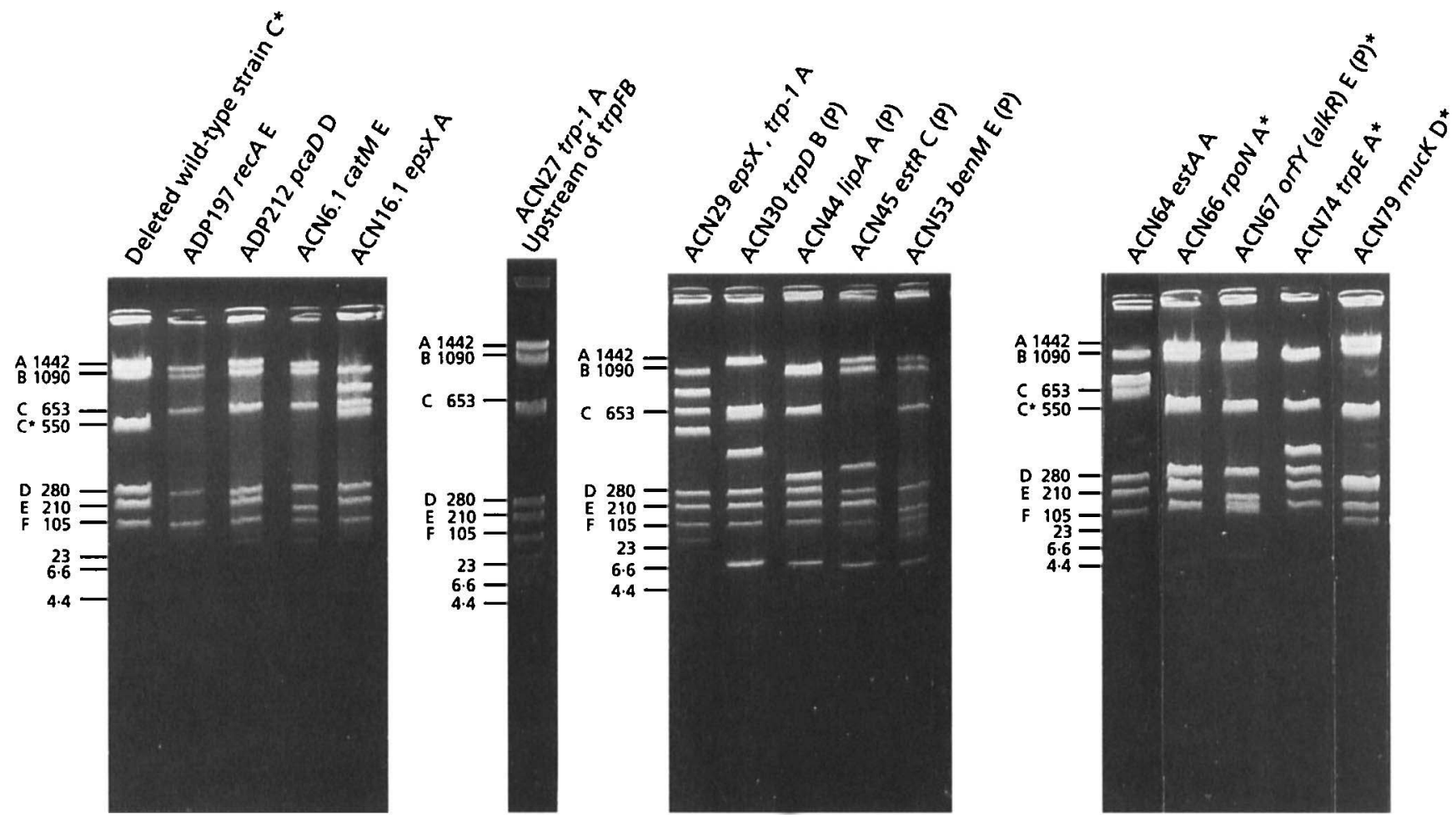

Fig. 6. TAFE gels of genomic DNA cleaved by Notl. The positions and sizes (in kbp) of the six wild-type fragments (A to F) and three size standards $(23,6 \cdot 6,4.4)$ are shown to the left of the gels. Strain designations and their mutated alleles are shown above each lane. Adjacent to each allele is the wild-type fragment cleaved by the Notl site(s) of the mutant. Strains with plasmids $(P)$ and those with fragment $C$ deletions $\left(C^{*}\right)$ are indicated $\left(^{*}\right)$. The $18 \mathrm{~h}$ protocol was used to separate fragments on the gels shown; other protocols were used on additional gels to resolve the smaller fragments better (not shown.)

The $\operatorname{trp} D$, est $R$ or $m u c K$ probes hybridized to wild-type Not I fragments B, C or D respectively. The sizes of B1 and $\mathrm{B} 2$ in $\mathrm{ACN} 30$ were 600 and $490 \mathrm{kbp}$, those of $\mathrm{C} 1$ and $\mathrm{C} 2$ in ACN45 were 430 and $220 \mathrm{kbp}$, while those of D1 and D2 in ACN79 were 240 and 40 kbp (Fig. 6). ACN45 appeared to carry a plasmid, whereas ACN79 had the $550 \mathrm{kbp}$ fragment $\mathrm{C}^{*}$.

In strains ADP197, ADP212 and ACN16.1 (Table 1), the recA, $p c a D$ or $e p s X$ genes are disrupted by $\operatorname{Tn} 5$, which contains NotI recognition sites. DNA probes made from the $\operatorname{rec} A, p c a D$ or eps $X$ genes hybridized to wild-type Not I fragments E, D or A respectively. In the recA mutant, ADP197, NotI cleavage generated two approximately $100 \mathrm{kbp}$ fragments, E1 and E2, that were indistinguishable in size from fragment $F$ in Fig. 6. D1 and D2 (250 and $30 \mathrm{kbp}$ ) were generated in the pcaD mutant, ADP212. A1 and A2 (830 and $615 \mathrm{kbp})$ were generated in the epsX mutant, ACN16.1 (Fig. 6).

\section{Relative orientations of genes}

The location and transcriptional direction of $\operatorname{lip} A$ were determined by hybridization of a lipA probe to wildtype NotI fragment A, I-CeuI fragment III and to NotI fragment A2 of ACN44 (Fig. 5). Probes from the $5^{\prime}$ end of epsX or a region upstream of $\operatorname{trp} E$ hybridized to fragment $\mathrm{A} 1$ of $\mathrm{ACN} 16.1$ or ACN74, respectively, indicating gene orientations. Additional orientations (Fig. 4) were deduced from the following information. Probes from the $3^{\prime}$ region of $t r p F$ or the $5^{\prime}$ end of $r p o N$ hybridized to the A2 fragments of ACN27 or ACN66. Probes downstream of alkR or catM hybridized to E1 of ACN67 or ACN6.1, respectively. Probes to the $5^{\prime}$ region of $m u c K$, or to a region downstream of $p c a D$, hybridized to D2 of ACN79 or ADP212, respectively.

A new strain was constructed to orient est $A$ since this gene was close to the centre of fragment A. In ACN65, both the estA $\Omega \mathrm{Km}$ cartridge and the lipA $\Omega S p S m$ cartridge were chromosomally inserted. NotI cleavage of this strain's DNA generated three smaller fragment A pieces. A probe from the $3^{\prime}$ region of $e s t A$ hybridized to the DNA between lipA and est A, establishing the est $A$ orientation. Similarly, Not I digestion of ADP197 indicated that $\operatorname{rec} A$ was in the centre of fragment $\mathrm{E}$. A new strain, ACN55, was constructed with benM disrupted by the $\Omega \mathrm{SpSm}$ cartridge and $\operatorname{rec} A$ disrupted by Tn5. A probe from the $5^{\prime}$ region of recA hybridized to the DNA fragment between benM and recA in ACN55, establishing the recA gene orientation (Fig. 4). 


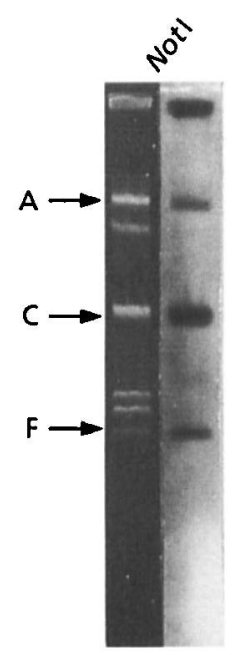

(a)

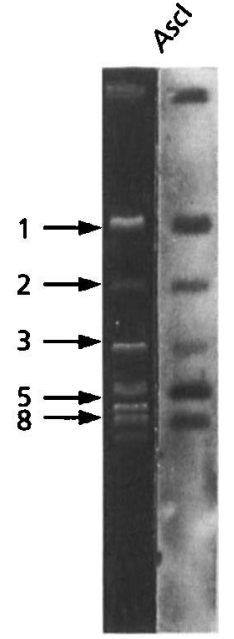

(b)
Fig. 7. Southern hybridization analysis of the chromosomal copies of IS1236. Wild-type DNA was digested with NotI (a) or Ascl (b) and separated on TAFE gels (left side of $a$ and b). Arrows indicate the fragments corresponding to hybridization signals (right side of $a$ and b) after using an IS1236-specific probe.

\section{Plasmid integration and plasmid maintenance in mutant strains}

A probe to the $3^{\prime}$ region of $\operatorname{trp} D$ hybridized to fragments $\mathrm{B} 1$ and $\mathrm{B} 2$ of strain $\mathrm{ACN} 30$, suggesting duplication of this region. In the construction of $\mathrm{ACN} 30$, the use of linearized plasmid pBAC51 DNA should have led to the acquisition of drug resistance by allelic replacement of the chromosomal with the modified $\operatorname{trpD}$ locus. However, if the transforming DNA contained some circular rather than linear plasmid, homologous recombination could have integrated pBAC51 in the genome, resulting in chromosomal copies of both the wild-type and modified $\operatorname{tr} p D$ alleles. A hybridization probe made to the vector portion of pBAC51 detected B1 of ACN30, indicating plasmid integration and demonstrating the trpGDC orientation (Fig. 4). Chromosomal integration of pBAC59 in the estR-disrupted ACN45 was similarly shown. A probe upstream of $e s t R$ hybridized to both $\mathrm{C} 1$ and $\mathrm{C} 2$ of ACN45. A probe to $\mathrm{pBAC} 59$ vector sequences hybridized to fragment $\mathrm{C} 1$, allowing est $\mathrm{R}$ orientation (Fig. 4).

In $\mathrm{ACN} 30$ and $\mathrm{ACN} 45$, plasmid vector probes hybridized not only to the chromosomally integrated copies of plasmids, but also to the smallest DNA fragments generated by Not I cleavage of total DNA. These fragments corresponded in size to the plasmids used in ACN30 and ACN45 construction, pBAC51 and pBAC59, each of which has a single NotI recognition sequence. The intensities of these small DNA fragments suggested that they were present in more than one copy (Fig. 6). Similar results were found for strains ACN44, ACN53 and ACN67 (Fig. 6). Moreover, appropriate gene probes hybridized to these smaller fragments, suggesting that these five strains carried autonomously replicating plasmids.

\section{Locations of rrn operons and IS1236 insertion sequences}

The restriction endonuclease I-CeuI recognizes a conserved 26 nucleotide sequence in bacterial rRNA operons (Liu et al., 1993). The presence of seven I-CeuI recognition sites indicated seven rRNA operons in ADP1. Consistent with the correlation between I-CeuI sites and rRNA operons, a ribosomal DNA probe (Dryden \& Kaplan, 1990) hybridized only to Not I fragments $A$ and D (data not shown).

Multiple copies of the insertion sequence IS1236 in ADP1 have been demonstrated (Gerischer et al., 1996). Their chromosomal locations were investigated here by Southern hybridization experiments with an IS1236labelled DNA probe (Fig. 7). The relative intensities of hybridization signals suggested several copies of this insertion sequence on the wild-type NotI fragment C. Hybridization to Ascl-generated fragment 5, which is internal to fragment $\mathrm{C}$, was also strong.

\section{DISCUSSION}

\section{Genome size and genetic organization}

This report presents the first physical and genetic map of the single, circular chromosome of Acinetobacter sp. strain ADP1. No evidence was found of endogenous plasmids. The genome size, $3 \cdot 8 \pm 0.2 \mathrm{Mbp}$, is in a similar range to those of strains of Rhodobacter, Salmonella, Escherichia, Bacillus and Pseudomonas (Fonstein \& Haselkorn, 1995). The number of ADP1 rRNA operons was found to be seven, the same as in Pseudomonas putida (Holloway et al., 1992) and E. coli (Ellwood \& Nomura, 1982). Strain ADP1 grows quickly on rich medium, with doubling times of approximately $40 \mathrm{~min}$, and the level of $r r n$ redundancy can provide the high ribosome levels needed for rapid growth (Condon et al., 1995). In a recent report, however, Stratz et al. (1996) demonstrated that in a BD413-derived strain of Acinetobacter sp., at least one rrn operon could be inactivated without decreasing growth rates or causing detectable physiological changes. Their results were also consistent with the presence of seven Acinetobacter rrn operons. In E. coli, the $r r n$ operons are clustered in one half of the chromosome, distributed around the origin of replication (Ellwood \& Nomura, 1982). In ADP1, six of the seven $r r n$ operons were clustered in approximately one-third of the chromosome, but the position of these operons relative to the origin of replication was not investigated.

The relative positions were determined, however, of two supraoperonic gene clusters involved in dissimilation of aromatic compounds. Localization of the $p c a D$ gene (map position 2555) determined the positions of the other known $p c a, q u i$ and $p o b$ genes (not all shown on the map) which constitute an approximately $20 \mathrm{kbp}$ 
region involved in the degradation of aromatic compounds via the protocatechuate branch of the $\beta$-ketoadipate pathway (Gerischer \& Ornston, 1995; Kloos et al., 1995). Moreover, the mucK gene involved in cis,cismuconate metabolism (P. A. Williams, personal communication), was found to be part of this cluster. Other genes involved in cis,cis-muconate metabolism, the catBCIJFD genes, are part of an approximately $20 \mathrm{kbp}$ ben-cat supraoperonic cluster encoding the catechol branch of the $\beta$-ketoadipate pathway (Ornston \& Neidle, 1991). Localization of catM, map position 2268 , established the relative positions of the other ben and cat genes, some of which are shown on the map. A region of $280 \mathrm{kbp}$ of DNA with unknown function separated the pob-qui-pca-muc cluster from the ben-cat cluster. Genes needed for aromatic compound degradation are also clustered in both P. putida PPN (ATCC 12633) and $P$. aeruginosa $\mathrm{PAO}$ (Holloway et al., 1990; Zhang et al., 1993).

The clustering of these catabolic genes in Acinetobacter sp. ADP1 is contrasted by the genomic separation of the trp genes needed for tryptophan biosynthesis (Haspel et al., 1991). In E. coli, there are five tryptophan genes, $\operatorname{trp} E D C B A$, which are contiguous in one operon, with the $\operatorname{tr} p D$ and $\operatorname{tr} p C$ genes encoding bifunctional enzymes. In Acinetobacter, the functions of the $\operatorname{trpD}$-encoded polypeptide are carried out by two proteins encoded by distinct genes, $\operatorname{trp} D$ and $\operatorname{trp} G$. Similarly, two genes, $\operatorname{trpC}$ and $\operatorname{trpF}$, encode the counterparts of the E. coli TrpC polypeptide. As shown in these studies, the locations of the $\operatorname{trp} E, \operatorname{trp} F B$, and $\operatorname{trp} G D C$ linkage groups are well separated on the ADP1 chromosome. The location of $\operatorname{trp} A$ was not determined. This arrangement is more similar to that of pseudomonads than enteric bacteria. In $P$. aeruginosa, there are at least four linkage groups, $\operatorname{trp} E, \operatorname{tr} p G D C, \operatorname{trp} F$ and $\operatorname{trp} B A$, which are found in three well-separated chromosomal locations (Haspel et al., 1991; Holloway et al., 1990; Schmidt et al., 1996).

\section{Mapping resolution}

Genes were precisely localized by the introduction of NotI recognition sites in the chromosome. Similar mapping approaches have used transposons or plasmids to introduce chromosomal restriction endonuclease recognition sequences (reviewed by Fonstein \& Haselkorn, 1995). The ability to transform the wild-type Acinetobacter strain with linear DNA or crude lysate DNA in this investigation simplified the mutagenesis procedure and facilitated the formation of strains with multiple mutations. It was possible to determine the transcriptional directions of individual genes and to provide a high-resolution genetic map. In contrast, the precision of gene localization by conventional hybridization methods is limited by the size of the smallest DNA fragment to which a probe hybridizes. In general, the greater the number of recognition sites for distinct endonucleases determined on a physical map, the greater the genetic mapping precision by hybridization. Extensive physical maps are often constructed for the purpose of improving gene-mapping resolution. With the methods used in these studies, a detailed physical map was not required.

Southern hybridization techniques, however, can be used to localize genes in ADP1 in those situations where interposon mutagenesis is not feasible to introduce specific DNA cleavage sites. Mapping precision can be increased by the selected use and combination of the engineered NotI sites in mutant strains. Cleavage of the wild-type chromosome with NotI yields several large DNA fragments that would not be useful as hybridization targets for gene localization. Smaller fragments can be generated by combining the interposon and/or transposon insertions in different strains to be present in a single strain. This method for cleaving large fragments into several smaller fragments was demonstrated in strains ACN55 and ACN65 used to orient the $r e c A$ and $e s t A$ genes, respectively.

Hybridization methods might identify the ADP1 homologues of genes isolated from other organisms. In vitro mutagenesis approaches were unsuccessful with several genes from A. calcoaceticus strains LMD79.41, NCIB 8250 and DSM 30007 (Gralton, 1996). Homology between the DNA in the heterologous Acinetobacter strains was apparently too low to introduce interposons into the ADP1 chromosome. With Southern hybridization techniques and reduced stringency conditions, distantly related genetic homologues might be identified.

\section{Variability in the size of Notl-generated fragment C}

During these investigations, a dramatic change was noted in the size of the wild-type DNA fragment C generated by chromosomal cleavage with NotI. Initially, the fragment $\mathrm{C}$ was consistently found to be $653 \mathrm{kbp}$ (Fig. 1). This is the size of the corresponding fragment in mutant strains ADP197, ADP212, ACN6.1, ACN16.1, ACN27, ACN30, ACN44, ACN53 and ACN54 (Fig. 6). In more recent TAFE analyses, however, the size of fragment $\mathrm{C}$ appeared to be $550 \mathrm{kbp}$. This smaller-sized fragment was designated $C^{*}$ (Fig. 6). Fragment $C^{*}$ was also observed in the most recently constructed mutants ACN66, ACN67, ACN74 and ACN79 (Fig. 6). These changes may reflect a spontaneous deletion which occurred in the laboratory version of the wild-type strain. Use of this strain as the recipient in subsequent transformation experiments would explain the presence of $\mathrm{C}^{*}$ in some mutants. The possibility that a deletion occurred independently in different strains, however, cannot be ruled out. No phenotypic differences have been correlated with the presence of $C^{*}$. Recent examination of NotI-digested DNA of strain ADP1 from L. $\mathrm{N}$. Ornston's laboratory detected a $653 \mathrm{kbp}$ fragment $\mathrm{C}$ (data not shown).

Fragment $C$ appeared to carry multiple copies of insertion sequence IS1236 (Fig. 7). The possibility that the deletion which occurred in fragment $\mathrm{C}$ is related to interactions between different copies of IS1236 remains to be investigated. In studies by Gerischer \& Ornston (1995), mutations leading to the inactivation of the 
pcaHG genes, located on NotI fragment D, were shown to have been caused by the spontaneous insertion of IS1236 in this genetic region. As shown in the present study (Fig. 7), the wild-type strain does not have DNA homologous to IS1236 located on fragment D, indicating the ability of IS1236 to move to distant chromosomal locations.

\section{Plasmids in Acinetobacter sp. ADP1}

In several mutant strains, plasmid integration rather than allelic replacement occurred despite the use of linearized DNA in their construction. This suggests that the transforming DNA contained some circular rather than linearized DNA, a possibility consistent with the apparent maintenance of plasmids within some strains. The plasmids used in these studies all had ColE1-type replicons, and it has previously been assumed that these plasmids do not replicate in Acinetobacter (Hunger et al., 1990). Nevertheless, several lines of evidence indicated their autonomous replication in ADP1. The sizes of the smallest fragments observed in NotI-digested chromosomal DNA from strains ACN30, ACN44, $\mathrm{ACN} 45, \mathrm{ACN} 53$ and ACN67 were the same as those of the plasmids used to generate these mutants. In Southern hybridization experiments these same small fragments hybridized to probes of either plasmid vector sequences or the genetic region of the corresponding plasmid. Moreover, there were eight NotI cleavage fragments in each of these mutant strains, even though introduction of a novel chromosomal NotI recognition site would have generated only seven fragments.

The relative intensities of the smallest DNA fragments (Fig. 6) indicated several copies of each plasmid being maintained within the bacterial cells. Mutant strains maintaining plasmids had additional drug resistance conferred by the cloning vector, and in some cases plasmids could be cured from the Acinetobacter sp. strain (Gralton, 1996). This latter observation and the observation that the plasmids were present in higher copy number than chromosomal DNA fragments suggested that they were not generated by excision from the chromosome by homologous recombination. Consistent with this interpretation, plasmid size and linearity always corresponded to the disrupted allele being carried on the vector whereas excision would be expected to generate fragments with either the wild-type or the disrupted allele.

In the studies of Hunger et al. (1990) the ColE1-based plasmid pBR322 was not stably maintained in Acinetobacter strains. Factors which affect the maintenance and replication of plasmids in ADP1 remain to be defined. It is important to be aware of the possible autonomous replication of ColE1-based plasmids, especially in experiments where they have been used as 'suicide' plasmids to target single-copy genetic constructs for chromosomal integration. TAFE methods allow the presence of plasmids to be readily assessed. These mapping studies provide the foundation not only for future Acinetobacter gene localization and taxonomy studies, but also for investigations of plasmid maintenance and stability.

\section{ACKNOWLEDGEMENTS}

We are grateful to the many colleagues, including those cited in Table 1, who generously contributed strains and plasmids for this study, many prior to publication. We thank A. L. English for assistance, T. Hoover, D. Krause and L. Shimkets for helpful comments, and A. Suwanto and K. Nereng for advice on TAFE methods. We also appreciate the contributions of Becky Bundy (isolation of the plasmids with junction fragments and construction of strain ACN16.1) and Lauren Collier (construction of plasmid pBAC6A and strain ACN6.1).

This research was supported by NSF grants MCB-9507393 and SGER-9415295. The US Department of the Army supported E.M.G. through the Advanced Civil Schooling Program.

\section{REFERENCES}

Averhoff, B., Gregg-Jolly, L. A., Elsemore, D. A. \& Ornston, L. N. (1992). Genetic analysis of supraoperonic clustering by use of natural transformation in Acinetobacter calcoaceticus. J Bacteriol 174, 200-204.

Baumann, P., Doudoroff, M. \& Stanier, R. Y. (1968). A study of Moraxella group II: oxidase negative species (genus Acinetobacter). J Bacteriol 95, 1520-1541.

Bergogne-Bérézin, E. (1994). Acinetobacter spp., saprophytic organisms of increasing pathogenic importance. Zentralbl Bakteriol 281, 389-405.

Condon, C., Liveris, D., Squires, C., Schwartz, I. \& Squires, C. L. (1995). rRNA operon multiplicity in Escherichia coli and the physiological implications of $r r m$ inactivation. J Bacteriol 177, 4152-4156.

Doten, R. C., Ngai, K.-L., Mitchell, D. J. \& Ornston, L. N. (1987). Cloning and genetic organization of the $p c a G$ gene cluster from Acinetobacter calcoaceticus. J Bacteriol 169, 3168-3174.

Dryden, S. C. \& Kaplan, S. (1990). Localization and structural analysis of the ribosomal RNA operons of Rbodobacter sphaeroides. Nucleic Acids Res 18, 7267-7277.

Ellwood, M. \& Nomura, M. (1982). Chromosomal location of the genes for rRNA in E. coli K-12. J Bacteriol 149, 458-468.

Elsemore, D. A. \& Ornston, L. N. (1994). The pca-pob supraoperonic cluster of Acinetobacter calcoaceticus contains quiA, the structural gene for quinate-shikimate dehydrogenase. $J$ Bacteriol 176, 7659-7666.

Eraso, J. M. \& Kaplan, S. (1994). $\operatorname{prrA}$, a putative response regulator involved in oxygen regulation of photosynthetic gene expression in Rhodobacter sphaeroides. J Bacteriol 176, 32-43.

Fonstein, M. \& Haselkorn, R. (1995). Physical mapping of bacterial genomes. J Bacteriol 177, 3361-3369.

Geissdठ̈rfer, W., Frosch, S. C., Haspel, G., Ehrt, S. \& Hillen, W. (1995). Two genes encoding proteins with similarities to rubredoxin and rubredoxin reductase are required for conversion of dodecane to lauric acid in Acinetobacter calcoaceticus ADP1. Microbiology 141, 1425-1432.

Gerischer, U. \& Ornston, L. N. (1995). Spontaneous mutations in $p c a H$ and $-G$ structural genes for protocatechuate 3,4dioxygenase in Acinetobacter calcoaceticus. J Bacteriol 177, 1336-1347.

Gerischer, U., D'Argenio, D. \& Ornston, L. N. (1996). IS1236, a 
newly discovered member of the IS3 family, exhibits varied patterns of insertion into the Acinetobacter calcoaceticus chromosome. Microbiology 142, 1825-1831.

Gerner-Smidt, P. (1994). Acinetobacter: epidemiological and taxonomic aspects. Acta Pathol Microbiol Immunol Scand Suppl $47102,5-41$.

Gralton, E. M. (1996). Physical and genetic map of Acinetobacter calcoaceticus strain BD413 (ADP1). MS thesis, University of Georgia, Athens, GA.

Gregg-Jolly, L. A. \& Ornston, L. N. (1990). Recovery of DNA from the Acinetobacter calcoaceticus chromosome by gap repair. $J$ Bacteriol 172, 6169-6172.

Gregg-Jolly, L. A. \& Ornston, L. N. (1994). Properties of Acinetobacter calcoaceticus recA and its contribution to intracellular gene conversion. Mol Microbiol 12, 985-992.

Harwood, C. S. \& Parales, R. E. (1996). The $\beta$-ketoadipate pathway and the biology of self-identity. Annu Rev Microbiol 50, 553-590.

Haspel, G., Hunger, M., Schmucker, R. \& Hillen, W. (1990). Identification and nucleotide sequence of the Acinetobacter calcoaceticus encoded trpE gene. Mol Gen Genet 220, 475-477.

Haspel, G., Kishan, V. \& Hillen, W. (1991). Organisation, potential regulatory elements and evolution of trp genes in Acinetobacter. In The Biology of Acinetobacter, pp. 239-249. Edited by K. J. Towner, E. Bergogne-Berezin \& C. A. Fewson. New York: Plenum Press.

Holloway, B. W., Dharmsthiti, S., Krishnapillai, V., Morgan, A., Obeyesekere, V., Ratnaningsih, E., Sinclair, M., Strom, D. \& Zhang, C. (1990). Patterns of gene linkages in Pseudomonas species. In The Bacterial Chromosome, pp. 97-105. Edited by K. Drlica \& M. Riley. Washington, DC: American Society for Microbiology.

Holloway, B. W., Escuadra, M. D., Morgan, A. F., Saffery, R. \& Krishnapillai, V. (1992). The new approaches to whole genome analysis of bacteria. FEMS Microbiol Lett 100, 101-106.

Hunger, M., Schmucker, R., Kishan, V. \& Hillen, W. (1990). Analysis and nucleotide sequence of an origin of DNA replication in Acinetobacter calcoaceticus and its use for Escherichia coli shuttle plasmids. Gene 87, 45-51.

Juni, E. (1972). Interspecies transformation of Acinetobacter: genetic evidence for a ubiquitous genus. J Bacteriol 112, 917-931.

Juni, E. (1978). Genetics and physiology of Acinetobacter. Annu Rev Microbiol 32, 349-371.

Juni, E. \& Janik, A. (1969). Transformation of Acinetobacter calcoaceticus (Bacterium anitratum). J Bacteriol 98, 281-288.

Kaplan, J. B., Goncharoff, P., Seibold, A. M. \& Nichols, B. P. (1984). Nucleotide sequence of the Acinetobacter calcoaceticus trpGDC gene cluster. Mol Biol Evol 1, 456-472.

Kloos, D.-U., DiMarco, A. A., Elsemore, D. A., Timmis, K. \& Ornston, L. N. (1995). Distance between alleles as a determinant of linkage in Acinetobacter calcoaceticus. J Bacteriol 177, 6015-6017.

Kok, R. (1995). Lipolytic enzymes in Acinetobacter calcoaceticus. $\mathrm{PhD}$ thesis, University of Amsterdam.

Kok, R. G., Christoffels, V. M., Vosman, B. \& Hellingwerf, K. J. (1993). Growth-phase-dependent expression of the lipolytic system of Acinetobacter calcoaceticus BD413: cloning of a gene encoding one of the esterases. J Gen Microbiol 139, 2329-2342.

Liu, S.-L., Hessel, A. \& Sanderson, K. E. (1993). Genomic mapping with I-CeuI, an intron-encoded endonuclease specific for genes for ribosomal RNA, in Salmonella spp., Escherichia coli, and other bacteria. Proc Natl Acad Sci USA 90, 6874-6878.

Neidle, E. L., Shapiro, M. K. \& Ornston, L. N. (1987). Cloning and expression in Escherichia coli of Acinetobacter calcoaceticus genes for benzoate degradation. J Bacteriol 169, 5496-5503.

Neidle, E. L., Hartnett, C. \& Ornston, L. N. (1989). Characterization of Acinetobacter calcoaceticus catM, a repressor gene homologous in sequence to transcriptional activator genes. J Bacteriol $171,5410-5421$.

Ornston, L. N. \& Neidle, E. L. (1991). Evolution of genes for the $\beta$ ketoadipate pathway in Acinetobacter calcoaceticus. In The Biology of Acinetobacter, pp. 201-237. Edited by K. J. Towner, E. Bergogne-Bérézin \& C. A. Fewson. New York: Plenum Press.

Rainey, F. A., Lang, E. \& Stackebrandt, E. (1994). The phylogenetic structure of the genus Acinetobacter. FEMS Microbiol Lett 124, 349-354.

Ross, C. M., Kaplan, J. B., Winkler, M. E. \& Nichols, B. P. (1990). An evolutionary comparison of Acinetobacter calcoaceticus trpF with $\operatorname{trpF}$ genes of several organisms. Mol Gen Genet 7, 74-81.

Sambrook, J., Fritsch, E. F. \& Maniatis, T. (1989). Molecular Cloning: a Laboratory Manual. Cold Spring Harbor, NY: Cold Spring Harbor Laboratory.

Schmidt, K. D., Tummler, B \& Romling, U. (1996). Comparative genome mapping of Pseudomonas aeruginosa PAO with $P$. aeruginosa $\mathrm{C}$, which belongs to a major clone in cystic fibrosis patients and aquatic habitats. J Bacteriol 178, 85-93.

Shanley, M. S., Neidle, E. L., Parales, R. E. \& Ornston, L. N. (1986). Cloning and expression of Acinetobacter calcoaceticus catBCDE genes in Pseudomonas putida and Escherichia coli. J Bacteriol $165,557-563$.

Smith, C. L. \& Cantor, C. R. (1987). Purification, specific fragmentation and separation of large DNA molecules. Methods Enzymol 155, 449-467.

Stark, M. (1996). PhD thesis, Tel-Aviv University.

Strätz, M., Mau, M. \& Timmis, K. N. (1996). System to study horizontal gene exchange among microorganisms without cultivation of recipients. Mol Microbiol 22, 207-215.

Suwanto, A. \& Kaplan, S. (1989). Physical and genetic mapping of the Rhodobacter sphaeroides 2.4 .1 genome: genome size, fragment identification and gene localization. J Bacteriol 171, $5840-5849$.

Towner, K. J. (1978). Chromosome mapping in Acinetobacter calcoaceticus. J Gen Microbiol 104, 175-180.

Towner, K. J., Bergogne-Bérézin, E. \& Fewson, C. A. (1991). Acinetobacter: portrait of a genus. In The Biology of Acinetobacter, pp. 1-24. Edited by K. J. Towner, E. Bergogne-Bérézin \& C. A. Fewson. New York: Plenum Press.

Yanisch-Perron, C. , Vieira, J. \& Messing, J. (1985). Improved M13 phage cloning vectors and host strains: nucleotide sequences of the M13mp18 and pUC19 vectors. Gene 33, 103-119.

Zhang, C., Huang, M. \& Holloway, B. W. (1993). Mapping of the ben, ant and cat genes of Pseudomonas aeruginosa and evolutionary relationship of the ben region of $P$. aeruginosa and P. putida. FEMS Microbiol Lett 108, 303-310.

Received 25 September 1996; revised 22 November 1996; accepted 29 November 1996. 